\title{
Student-created videos as a performance task in science
}

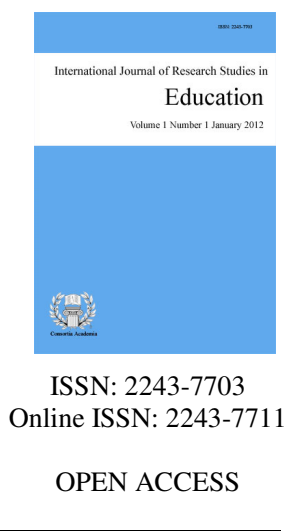

\section{Abstract}

To keep our students engaged in learning, teaching methods have evolved over the years and have adapted the use of technology. This study aimed to determine the students' attitudes towards creating videos as well as the perceived effects in skills, competency, interest, engagement, and value, and also their insights and reflections. A total of 54 Grade 10 students of CBFMNHS participated in the study. A researcher-made descriptive survey was used to identify the attitude and perception of students towards creating videos. The survey also included open-ended questions where students provided personal feedback regarding their learning experience. The researcher also collected data from the video samples. Basic descriptive statistical tools such as frequency counts, percentages, and ranks were used on the processing and interpretation of the quantitative data section of the questionnaire. Content analysis was used in the open-ended questions to reveal the insights, comments, suggestions, and reflections of the students. The data shows that $92.59 \%$ of the students have a positive attitude in creating videos. In terms of perception, the students agree that creating videos helped develop certain competencies in using ICT, collaborative learning, creativity, critical thinking, and communication skills. The data reveals that students get to enjoy Science when they created videos. The students also agree that student-created videos are valuable, informative, and very useful in their learning and in sharing information with other students. In terms of insights, the self-reflection of the students show that they are happy about the outcomes of their performance task. Their success depends on cooperation, creativity, confidence, effort, teamwork, and listening to the opinion of others. Also, the student-created videos reflect what the students have learned about the lesson. It was concluded that student-created videos serve as a good performance task in Science among selected Grade 10 students of CBFMNHS. It may serve as a basis for having a Science fair that includes amateur video making contest about certain topics.

Keywords: student-created videos; performance task; videos 


\section{Student-created videos as a performance task in science}

\section{Introduction}

"What I hear, I forget. What I see, I remember. What I do, I understand." This famous line from Confucius gives an idea of how students learn the best when they are involved. When they act. When they do something worthwhile. How do teachers keep students engaged in learning? Is it sure that they have learned? Teaching methods have evolved over the years, and to keep being updated with the changes, everyone has adopted the use of technology. To keep in touch with them, teachers find new ways of motivation.

Videos have been a part of the education system. As a Science teacher, this multimedia is very useful since curiosity cannot be satisfied by textbooks and teachers alone. True enough, experience is the best teacher, but not in all cases. The researcher herself use videos to demonstrate processes that cannot be done in the classroom setting, just like explaining some concepts of Plate Tectonics. But still, that does not solve the problem. How do we involve them? Many 21st century children are "born with smartphones in their hands". As early as 3 years old, they are exposed to and know how to operate tablets, phones, laptops. Students nowadays are digital learners, and they typically enjoy working with technology (Bourke, 2015).

Also, since the Internet is widely used and readily accessible, people easily share information through videos. This is quite easy nowadays since phone companies started designing all-in-one gadget that can be used for (almost) all your documentation needs: the user-friendly smartphones can do anything, from being a camera, tape recorder, video recorder, computer (processing information), calculator, clock, calendar. Also, many applications make it easy to edit and share various media, like Viva Video, Quik Video Editor, We Video, Vid Trim Pro, and a lot more. Surprisingly, these applications can be downloaded for free. How can we take advantage of these things? While presenting videos are very helpful for teachers in delivering lessons, how about making students demonstrate learning through creating videos? This study focused on student-created videos and how they can be used as an aid in learning.

\section{Literature review}

\subsection{Performance tasks}

Effective School Year 2015-2016, the Policy Guidelines on Classroom Assessment for the K to 12 Education Program has been implemented in public elementary schools nationwide. Enclosed in the DepEd order includes assessment in the classroom which aimed at helping students perform well concerning the learning standards: content standards, performance standards, and learning competencies. Performance standards describe the abilities and skills that learners are expected to demonstrate about the content and integration of 21st-century skills. In the new grading system, student activities are classified into two: written works and performance tasks. Performance tasks allow learners to show what they know and what they can do in diverse ways through group presentations, oral works, research projects, etc. these activities are now indicated in textbooks (D.O. 8, s., 2015).

\subsection{Experiential learning}

"Experiential learning is the application of theory and academic content to real-world experiences, either within the classroom, within the community, or within the workplace, which advances program or course-based learning outcomes that are specifically focused on employability skills. Experiential learning requires the student to not only engage in the experience activity but also requires them to reflect upon their learning and how their skills learned through their academic studies can be applied beyond the classroom" (Educational Development

2 Consortia Academia Publishing (A partner of Network of Professional Researchers and Educators) 
Centre, n.d.).

According to the Educational Development Centre of Carlton University, experiential learning makes learning relatable to students, increases the effectiveness of learning, links theory to practice, increases students' engagement, assists in memory retention, and leads to the development of skills for lifelong learning. The same paper stated that based on Kolb's theory, the students have different learning styles that are influenced by the social environment, previous educational experiences, and learners' cognitive makeup.

\subsection{Use of smart phones}

Undeniably, smartphones have become a part of our society. Most teens today have access to social media. According to the Pew Research Center, 95\% of US teens are using smartphones. 45\% of teens say they are online on a near-constant basis. Meanwhile, according to a survey conducted by statista.com in 2016, 25.38 percent of the population in the Philippines used a smartphone. In 2017, the number of smartphone users in the Philippines was estimated to reach 30.4 million. This would mean that around 32 percent of the population in the Philippines would use a smartphone. This number is expected to rise to 40 percent by the year 2021. Also, Statista.com (2017) conducted a survey which revealed that in 2016, the Philippines had 50.77 million internet users. This figure is projected to grow to 57.84 million internet users in 2022.

Notable literacy organizations, such as the International Reading Association (IRA) and the National Council of Teachers of English (NCTE) (1996), as cited by Morgan (2013), have added standards emphasizing the need for teachers to use media other than books, including video, and more organizations will likely add similar standards soon. Morgan (2013) agrees that video-making technology is more affordable, more user-friendly, and more powerful than ever because students nowadays have cellphones, cameras, and other hand-held devices that can capture videos, making video creation easy for teachers to implement. In his research, he found out that video production among students can lead to many positive academic outcomes, and teachers can easily incorporate it into the classroom. Siegle (2009), as cited by Morgan, stated that young people are not only surrounded by visual images but also naturally attracted to viewing and producing videos.

If used properly, smartphones can be used in making video projects that can engage and motivate students in learning, since students tend to enjoy viewing videos. Nielsen (2009), as cited by Morgan (2013), noted that each year, teens are viewing videos at an increasing rate. Morgan also cited in a study conducted by Spires, Hervey, Morris, and Stelpflug (2012) that a growing number of teenagers use video to communicate and express themselves. "By providing projects that match this trend, educators can use video production as a method to tap into pupils' interests and thus engage students to learn across the curriculum (Spires et al., 2012). Siegle (2009) contends that in addition to being a great motivator for all students, videos also can allow some students to learn a concept more clearly" (Morgan, 2013).

\subsection{Video in the classroom}

Videos in a classroom are convenient and versatile ways to involve students and assist teachers and different educational institutions. Based on the results of the study conducted by Peterson (2016), most students enjoyed the project and demonstrated more engagement than other types of assessments like essays and individual technology-based projects. Students have the opportunity to be more creative when working in groups. In a study conducted by Dinagsao (2017), creating videos played a critical role in increasing the degree of understanding concepts of the lessons among students. The majority of the students reported that they learned new skills such as video editing and using video software while completing the requirements. They also expressed some social, leadership, self-confidence, and time management skills were learned. Patience working with a partner was expressed as a virtue developed in doing the video projects. Students shared their experiences in terms of planning, organizing, collaborating, writing, and analyzing. The videos showed the level of critical thinking used as well as creativity to explain some mathematical concepts. 
Greene and Crespi (2012) investigated the perceived value of student-created videos as a tool for enhancing the learning experience. The results of the research suggest that students appreciate the video experience; they find it relevant and entertaining. They also report that it helps reinforce concepts they have been exposed to in class. Ting (2012) emphasized that student-created videos help in boosting the learner's confidence and elevate their sense of achievement. Students learn to take charge of their learning. Also, working in groups engage learners in cooperative learning and helps enhance communication skills such as negotiation of meaning, decision-making, and teamwork. It also caters to the different learning styles of a heterogeneous classroom because of the different roles they play.

\subsection{Research questions}

This study was undertaken to find out the usefulness of student-created videos as a performance task in Science of selected Grade 10 students of CBFMNHS. Specifically, the following questions were answered:

A. What is the profile of the respondents?

$$
\begin{aligned}
& >\quad \text { Age } \\
& >\quad \text { Sex }
\end{aligned}
$$

B. What is the attitude of the students towards creating videos?

C. What are the perceived effects of creating videos to students in terms of:

$$
\begin{aligned}
& >\quad \text { skills and competencies; } \\
& >\quad \text { student interest/engagement; and } \\
& >\quad \text { project value/format }
\end{aligned}
$$

D. What are the insights and reflections of the students in creating videos?

\subsection{Significance of the study}

The findings of this study can help teachers determine the students' attitudes towards creating videos as well as the perceived effects in skills, competencies, interests, engagement, and values, and also their insights and reflections through their responses during the survey and written reflections. Specifically, this study aimed to determine the students' experiences in terms of collaborating with others, their challenges or difficulties in creating the video. With the students' reflections, the study identified their insights, extent of using collaborative skills, other technology skills learned, and their level of engagement.

\section{Research methodology}

Sampling - The target population was Grade 10 students of CBFMNHS. Out of the 62 students who created videos, 54 were selected using the Slovin's formula and were used as a sample from the population through random sampling method.

Data collection - This study used a researcher-made descriptive survey to identify the attitude and perception of students towards creating videos. The survey also included open-ended questions where students provided personal feedback regarding their learning experience. The researcher also collected data from the video samples. When completed properly, it can provide valuable information about the quality and appropriateness of student learning.

Ethical issues - Privacy concerns and fair use of technology are concepts that needed to be addressed before students embarking on their assignments. The teacher provided a relevant structure and guidelines. Attention was

4 Consortia Academia Publishing (A partner of Network of Professional Researchers and Educators) 
stressed on cases where students intend to use video or audio recordings of others. Thus, students were required to cite the sources of the video and audio recording to be used. Consent forms were also provided by the researcher to be signed by the participants and interviewees. Participants' anonymity and confidentiality were ensured and relevant ethical concerns were addressed appropriately.

\section{Data analysis}

Since the study did not require the use of any inferential statistics, basic descriptive statistical tools such as frequency counts, percentages, and ranks were used on the processing and interpretation of the quantitative data section of the questionnaire. Content analysis was used in the open-ended questions since it involves coding and classifying the data, also referred to as categorizing and coding or indexing. Content analysis aims to make sense of data and to make inferences about the messages or findings. It is a research method for subjective interpretation of the content of text data through a systematic classification process of coding and identifying themes and patterns (Hsieh \& Shannon, 2005).

A total of 54 students participated in the survey. The first part of the questionnaire was about the profile of the student. Their ages ranged from 14 to 18 years old. 22 were male and 32 were female.

\section{Table 1}

Profile of the participants according to age

\begin{tabular}{|c|c|c|}
\hline Age & Frequency & Percentage \\
\hline 14 & 1 & $2 \%$ \\
\hline 15 & 31 & $57 \%$ \\
\hline 16 & 10 & $19 \%$ \\
\hline 17 & 10 & $19 \%$ \\
\hline 18 & 2 & $4 \%$ \\
\hline Total & 54 & $100 \%$ \\
\hline
\end{tabular}

\section{Table 2}

Profile of the participants according to sex

\begin{tabular}{|c|c|c|}
\hline Sex & Frequency & Percentage \\
\hline Male & 22 & $41 \%$ \\
\hline Female & 32 & $59 \%$ \\
\hline Total & 54 & $100 \%$ \\
\hline
\end{tabular}

The second part of the survey tool was about the attitude of the students toward video creation. It was about their point of view after finishing creating videos.

\section{Table 3}

Students' attitude towards video creation

\begin{tabular}{|c|c|c|c|c|}
\hline Response & Students' attitude towards video creation & $f$ & $\%$ & $+/-$ \\
\hline \multirow{2}{*}{ Positive } & I loved it and I want to do it again. & 24 & $44.44 \%$ & $92.59 \%$ \\
\hline & It was ok. & 26 & $48.15 \%$ & \\
\hline \multirow{2}{*}{ Negative } & It was not my favorite. I would rather do something else next time. & 4 & $7.41 \%$ & $7.41 \%$ \\
\hline & I did not like it at all and do not want to do it again. & 0 & & \\
\hline & Total & 54 & $100 \%$ & $100 \%$ \\
\hline
\end{tabular}

Data shows that more students felt ok doing videos, $3.17 \%$ more than students who loved and wanted to do videos again, while 4 out of 54 students said that they would rather do other projects because it was not their favorite, and none of them did not like creating videos at all. The data also shows that students who created videos had a $92.59 \%$ positive attitude in creating videos.

The third part of the survey tool was about the perception of students toward video creation. The Likert scale 
Baclay, L. J.

is used to determine the effectiveness of the performance task to their skills and competencies, interests and engagement to Science, and its value and format.

\section{Table 4}

Range and verbal interpretation of variables

\begin{tabular}{ccl}
\hline Range & Scale & \multicolumn{1}{c}{ Verbal Interpretation } \\
\hline 5 & $4.21-5.00$ & Strongly Agree \\
4 & $3.41-4.20$ & Agree \\
3 & $2.61-3.40$ & Neutral \\
2 & $1.81-2.60$ & Disagree \\
1 & $1.00-1.80$ & Strongly Disagree \\
\hline
\end{tabular}

\section{Table 5}

Perception of students towards creating videos in terms of skills/competencies

\begin{tabular}{lccc}
\hline \multicolumn{1}{c}{ Completing the video project helped me develop skills in: } & Mean & Interpretation & Rank \\
\hline 1. Working in a group & 4.06 & Agree & 2 \\
2. Using technology like cellphone and video camera & 4.31 & Strongly Agree & 1 \\
3. Editing video & 3.80 & Agree & 3 \\
4. Being creative & 3.78 & Agree & 4.5 \\
5. Moving around and learning "hands-on" & 3.56 & Agree & 8 \\
6. Speaking in front of the camera & 3.61 & Agree & 7 \\
7. Formulating interview questions & 3.78 & Agree & 4.5 \\
8. Talking/Interviewing different people & 3.76 & Agree & 6 \\
& Average & 3.83 & Agree \\
\hline
\end{tabular}

Table 5 shows that students strongly agree that using technology like cellphones and video cameras is the most developed skill in making videos. The second highest skill is working in a group, next is editing video, being creative in formulating interview questions, interviewing different people, followed by speaking in front of the camera, and being hands-on. This proves that creating videos develops the competencies of students in using ICT, creativity, collaborative learning, critical thinking, and communication skills. These skills are essential for developing 21st-century learners. Performance standards describe the abilities and skills that learners are expected to demonstrate about the content and integration of 21 st-century skills.

\section{Table 6}

Perception of students toward creating videos in terms of interest/engagement

\begin{tabular}{lccc}
\hline \multicolumn{1}{c}{ Completing the video project has helped me to: } & Mean & Interpretation & Rank \\
\hline $\begin{array}{l}\text { 1. Increase my interest in learning about tectonic-related disaster } \\
\text { preparedness }\end{array}$ & 4.09 & Agree & 3 \\
$\begin{array}{l}\text { 2. Work hard at being knowledgeable about the tectonic plates and } \\
\text { disaster preparedness }\end{array}$ & 4.11 & Agree & 2 \\
$\begin{array}{l}\text { 3. Enjoy the Science class } \\
\text { 4. Feel like I accomplished something worthwhile }\end{array}$ & $\begin{array}{l}4.44 \\
\text { Strongly Agree }\end{array}$ & 1 \\
& 3.93 & $\begin{array}{l}\text { Agree } \\
\text { Agree }\end{array}$ & 4 \\
\hline
\end{tabular}

Table 6 shows that students strongly agree that they enjoy the Science class more when they created videos. They also agree that video making has helped them work hard at being knowledgeable about tectonic plates and disaster preparedness, followed by increased interest in learning about tectonic-related disaster preparedness, and feeling accomplished something worthwhile. This means that creating videos can help in motivating and increasing student engagement.

For table 7, the mean of the students' responses in all items falls under "Agree". The item that gained the highest mean is "I recommend making videos to other students and schoolmates", followed by "I would like to do videos again next time", and "my finished video is a useful informative material for other students". This 
means that the students agree that student-created videos are valuable, informative, and very useful in their learning and in sharing information with other students.

\section{Table 7}

Perception of students toward creating videos in project value and format

\begin{tabular}{lccc}
\hline \multicolumn{1}{c}{ Value } & Mean & Interpretation & Rank \\
\hline 1. I recommend making videos to other students/schoolmates. & 4.20 & Agree & 1 \\
2. I would like to do videos again next time. & 4.04 & Agree & 2 \\
3. My finished video is a useful informative material for other students. & 3.91 & Agree & 3 \\
& Average & 4.05 & Agree \\
\hline
\end{tabular}

The last part of the questionnaire reveals the insights, comments, suggestions, and reflections of the student. The self-reflection part reveals that student can assess their learning by analyzing and understanding the process and outcomes of the activity. The following are written verbatim and had undergone minor editing to be easily understood.

\section{$\underline{\text { Positive comments }}$}

- Making video is creative and beautiful.

- I am so happy.

- The video we made is very good.

- Our video is very beautiful because we know how to handle our group and we have respect to each other so that our video presentation is (effortness)

- It was so fun. it can develop your skill in talking in front of cameras.

- In making video is so interested (interesting).

- We learn a lot from this video.

- It's hard to make but it's easy to watch coz it's so beautiful.

- It's all creative and its help(s) others to speak in front of camera to talking (to) other people.

- It's beautiful if all member(s) participate. Everyone needs unity.

- I'm not shy anymore of (in) front of the camera.

\section{$\underline{\text { Things learned in video making process }}$}

- We learned how to edited (edit) the videos and insert the effects.

- The most important that you (I) learned in making videos is speaking in front of camera and editing the video and being creative.

- Team work and work hard at being knowledgeable.

- The most important thing that I learned in creating videos is helping each other and participate to your group.

- Best editing apps. Give the best of performing on camera. Let (what) your (you're) talking about are (be) clearly deliver(ed). Be wise for editing.

- The important that I learned in creating videos is to being creative and make my confidence okay and working to my groupmates.

- I learned all about how to speak and interview other people. 
Baclay, L. J.

- The most important in the video is materials and good looking for everyone and always smile and (say) thank you after the video.

\section{$\underline{\text { Advice and suggestions }}$}

- The most important in creating a video is (make) the voice always loud so it will encourage the viewers to watch the video and it is clear to hear and enjoyable to watch.

- Double check everything and increase the level of editing.

- In making video, take the advice of other people specially from those "who knows" how to make video. The contents must be worth it and connected to the topic that was given.

- (It is important) To hear out the different opinions of different persons.

- Make some videos look more reality.

- Search a place that has a quiet place to take good interview.

- Just be patient in editing your videos.

- First we need to cooperate and think twice what (the) video (is) about, what (is) the first to do to avoid wrong decision. Complete group is important actually.

- Inspect the surroundings and don't do too much O.A. editing.

- Clear your voice the speak louder the clear the camera and editing.

- In creating video, it must be clear, the voice and the editing must be catchy that the viewer will be encourage(d) to view the video.

- Time is gold. We need to use right the time because time is important.

\section{Self-evaluation}

- The video is good but kulang ng mga details and etc.

- My comments in making the video is my other groupmates are not participating.

- Don't (be) absent in practice.

- My members is (are) lazy.

- It was ok for me but next time give your best all the time.

- It is noisy.

\section{Lessons learned in the video}

- The best thing that I learned in creating videos is to get ready for the incoming disaster.

- The most important materials/things that we must always bring is the first aid kit, hygiene kit, medicines, food, clothes and etc. during disasters.

- We won't know when the earthquake came (will come) so we have to be educated and be ready at all times.

- I learned that the important thing when there's a(n) earthquake (is) just don't be afraid and keep calm to survive during earthquake. 
Although not written, the researcher also included some of the things that are evident in the videos. The students tackled the things to be done before, during, and after the earthquake. They also emphasized the importance of duck, cover, and hold, being calm, going to a safe place after the earthquake, and preparing for the aftershock.

It can be observed that they were happy and they enjoyed the videos they made. Although they also took note of the things to be considered next time. They also had the opportunity to criticize their works that could lead to self-assessment. It can be said that the video-making process is suitable for $21^{\text {st }}$-century students. Collaborative learning, use of technology, communication skill, critical thinking, and creativity are reflected in their comments. According to Partnership in $21^{\text {st }}$ Century Learning (2019), within the context of key knowledge instruction, students must also learn the essential skills for success in today's world, such as critical thinking, problem-solving, communication, and collaboration.

\section{Summary of findings}

This study was undertaken to find out the usefulness of student-created videos as a performance task in Science of selected Grade 10 students of CBFMNHS. The findings are hereby summarized.

Attitudes of students towards creating videos - The students have a positive attitude towards making videos. It is acceptable for the students to create their videos as a performance task.

Perception of students towards creating videos - a) The students agree that creating videos helped develop certain competencies in using ICT, collaborative learning, creativity, critical thinking, and communication skills. b) The data reveals that students get to enjoy Science when they created videos. This means that creating videos can help in motivating and increasing student engagement. c) The students agree that student-created videos are valuable, informative, and very useful in their learning and in sharing information with other students. Creating videos is a good performance task since it allows students to show what they know and what they can do in diverse ways.

Insights and reflections in creating videos - a) Self-reflection of the students show that they are happy about the outcomes of their performance task. Their success depends on cooperation, creativity, confidence, effort, teamwork, and listening to the opinion of others. b) The student-created videos reflect what the students have learned about the lesson.

\section{Conclusions}

Based on the findings, the researcher arrived at these conclusions.

$>\quad$ Student-created videos serve as a good performance task in Science among selected Grade 10 students of CBFMNHS.

$>$ Student-created videos as a performance task help develop 21st-century skills such as ICT, creativity, collaborative learning, critical thinking, and communication skills.

$>\quad$ Student-created videos as a performance task can increase student engagement since it helps in motivation and enjoyment of the subject.

$>\quad$ Student-created videos as a performance task serve as a valuable and informative tool for student learning and sharing information.

$>$ Student-created videos as a performance task also give them a sense of achievement as it also increases the confidence of the students. They also have learned the importance of effort and listening skills. 


\subsection{Recommendations}

Based on the findings and conclusions of the study, the following are recommended:

$>$ Teachers must consider student-created videos as a performance task in Science and other subjects. Performance tasks need to develop $21^{\text {st }}$-century skills.

$>$ Teachers must consider being updated about the trends in technology today and in social media to help in increasing the interests of the students.

$>\quad$ The responsible use of smartphones for performance tasks inside the classroom may also be considered since this gadget also has programs and applications that are almost the same as computer units and it also can be used as a portable minicomputer.

$>\quad$ Students can use this as an advantage because they fast learners when it comes to technology, and this performance task is technology-based.

$>\quad$ Since teenagers today enjoy viewing videos online, it is better if we encourage them to upload videos they made themselves that are related to learning and education.

$>\quad$ Parents are encouraged to support their children in doing such performance tasks and in viewing other student-created videos that can enhance their learning even outside the school.

$>$ Schools may consider having a Science fair that includes amateur video making contest about certain topics.

\section{References}

Bourke, N. (2015, July 17). Test their knowledge using student-created videos. Retrieved from https://www.iste.org/explore/In-the-classroom/Test-their-knowledge-using-student-created-videos

Dinagsao, A. V. (2017). Student-created videos as assessment of learning in the mathematics classroom:

Pre-Service teachers' experiences and reflections. International Journal of Advanced Research, 5(11), 398-402. https://doi.org/10.21474/ijar01/5782

DO 8, s. (2015, April 1). Policy guidelines on classroom assessment for the K to 12 basic education program. Retrieved from http://www.deped.gov.ph/2015/04/01/do-8-s-2015-policy-guidelines-on-classroom-assessment-for-the-k -to-12-basic-education-program/

Educational Development Centre. (n.d.). What is experiential education? Retrieved from https://carleton.ca/experientialeducation/what-is-experiential-education/

Greene, H., \& Crespi, C. (2012). The value of student created videos in the college classroom: An exploratory study in marketing and accounting. Retrieved from https://www.internationaljournal.org/images/Greene.pdf

Hsieh, H., \& Shannon, S. (2005). Three approaches to qualitative content analysis. Qualitative Health Research, 15(9), 1277-1288. https://doi.org/10.1177/1049732305276687

Morgan, H. (2013). Technology in the classroom: Creating videos can lead students to many academic benefits. Childhood Education, 89(1), 51-53. https://doi.org/10.1080/00094056.2013.757534

Partnership for $21^{\text {st }}$ Century Learning. (2019). Framework for $21^{\text {st }}$ century learning definitions. Battle for Kids. http://static.battelleforkids.org/documents/p21/P21_Framework_DefinitionsBFK.pdf

Peterson, M. (2016, December). Digital video as a summative assessment tool. Retrieved from https://sophia.stkate.edu/cgi/viewcontent.cgi?article=1187\&context=maed

Spires, H. A., Hervey, L. G., Morris, G., \& Stelpflug, C. (2012). Energizing project-based inquiry: Middle-grade students read, write, and create videos. Journal of Adolescent \& Adult Literacy, 55(6), 483-493. https://doi.org/10.1002/JAAL.00058

10 Consortia Academia Publishing (A partner of Network of Professional Researchers and Educators) 
Statista.com. (2017, July). Smartphone users in the Philippines 2017. Retrieved from https://www.statista.com/statistics/467186/forecast-of-smartphone-users-in-the-philippines/

Ting, N. C. (2013). Classroom video project: An investigation on students' perception. Procedia-Social and Behavioral Sciences, 90, 441-448. https://doi.org/10.1016/j.sbspro.2013.07.113 